\title{
Verkondiging deur musiek: 'n Aspek van kreatiewe geloofskommunikasie
}

\author{
Elsabé Kloppers \\ Departement Musiek \\ Universiteit van Pretoria
}

\begin{abstract}
Communicating faith creatively through music

The question of music ministry has become a focal point in the Dutch Reformed Church. The debate arises primarily from discontent about rigid and uninspired musical practices in the church. These practices are promoted and affirmed by one-sided theological views, according to which the spoken word as God's Word, is over-emphasized, and proclamation through music and other means is denied. In some Reformed churches this one-sidedness led to responses in the form of a music ministry with new one-sided approaches. In this article it is argued that music, singing and other forms of art need to be recognized and promoted as ways of communicating the Gospel on various levels. An encompassing strategy for creative communication of the faith within a more active liturgy needs to be developed. Liturgists need to be well-trained for such an encompassing task.
\end{abstract}

\section{VRAAGSTELLING EN KONTEKS}

Binne die Nederduitsch Hervormde Kerk het die vraag na "musiekbediening" die laaste tyd na vore gekom. Die oorsprong van die vraag is meervoudig. In baie gemeentes het die musiekpraktyke in die erediens strak, geyk en ongeïnspireerd geraak en is in vaste liturgiese vorme verval. By sommige lidmate bestaan ook die persepsie dat die prinsipiële uitgangspunte binne die Ned Herv Kerk, en trouens binne die gereformeerde tradisie as sodanig, te rigied is. Lidmate se behoeftes ten opsigte van die erediens en die musiek in die erediens is ook nie meer (noodwendig) dieselfde as twintig of dertig jaar gelede nie. Vir sommige lidmate en predikante sonder voldoende agtergrond ten opsigte van teologiese 
uitgangspunte, musikale moontlikhede en liturgiese vormgewing, lyk die inbring van 'n gospelgroep, poporkes en/of klawerbord en (voor)sanger(s) na 'n eenvoudige oplossing. Die optrede van so 'n sanger, begeleidingsgroep of poporkes word dikwels spesifiek as ' $\mathrm{n}$ musiekbediening getipeer. Die siening geld ook vry algemeen dat vir musiekbediening nie (noodwendig) die liedere in die amptelike bundels gebruik word nie, maar dikwels juis liedere met ' $n$ ander inslag as dié in die amptelike bundels. Die beskrywing "musiekbediening" word ook dikwels eksklusief vir groepe soos popgroepe, gospelsangers en dies meer gebruik, as sou daar net één vorm van "musiekbediening" moontlik wees, en as sou "tradisionele" orrelbegeleiding en die benadering van 'n bekwame liturg wat musikale en liturgiese moontlikhede maksimaal ontsluit, nie onder dié term tuiskom nie.

Die saak, sowel as die term musiekbediening, is dus verwarrend. Dit blyk ook uit die memoranda van lede van die Komitee vir Kerkmusiek oor dié saak. Daar is diegene wat musiekbediening eensydig verstaan volgens die praktyke wat tans in baie charismatiese kerke en in sommige gemeentes van die NG Kerk aan die orde is - en wat inderdaad dié vorm van musiekbediening teenstaan. Op grond van onduidelik gebruikte terminologie, word die saak van musiekbediening as sodanig dan afgewys. Daar is diegene wat glo dat verkondiging of "bediening" deur musiek en sang nie kan plaasvind nie en wat die saak van musiekbediening inderdaad afwys. Daar is egter ook diegene wat op grond van oortuiging rakende die verkondigingsmoontlikhede van musiek, die saak van musiekbediening prinsipieel steun, maar wat op grond van die onkritiese en verwarrende gebruik van die term die woord musiekbediening eerder wil vermy - ook omdat die term, vanweë die beslag wat in praktyk reeds so wyd daaraan gegee word, nie meer sonder "bagasie" kan funksioneer nie.

Hierdie uiteenlopende standpunte in verskillende memoranda, is lukraak bymekaar gegooi en as "memorandum" aan die ses-en-sestigste Algemene Kerkvergadering voorgelê (Agenda 2001:267-270). So 'n verslag kon nie werklik bydrae tot 'n sinvolle en gestruktureerde gesprek nie. $\mathrm{Na}$ 'n uitgebreide bespreking, het die Algemene Kerkvergadering wel tot die volgende besluit 
gekom: "Die evangelie kan binne die etos van die Nederduitsch Hervormde Kerk deur sang en musiek verkondig word. Die implikasies - beide fundamenteel en prakties - moet verder bestudeer word" (Besluitebundel 2001:141). Die term musiekbediening - wat aanleiding tot die bespreking gegee het - is in die besluit vermy.

In hierdie artikel word aangesluit by die huidige gesprek binne die Nederduitsch Hervormde Kerk van Afrika, breër teologiese standpunte gestel, en met verwysing na moontlikhede in die nuwe Liedboek, 'n aantal breë moontlikhede aangedui waarvolgens musiek maksimaal in die erediens kan funksioneer. Die gevolgtrekking is dat musiek as verkondigingsmoontlikheid in die erediens eers ten volle benut kan word waar die liturgie as geheel diepgaande aandag geniet, en waar alle ander wyses van evangelie-verkondiging, soos verkondiging deur kuns en ander visuele vorme, ook grondig bedink word.

'n Omvattende strategie van geloofskommunikasie moet gevolg word, ten einde die mens as geheel in 'n veranderende geestesklimaat aan te spreek en te betrek, en om die volle omvang van die evangelie in haar vele dimensies kreatief te kommunikeer.

There are many important liturgical issues facing the Reformed churches today. One is that in so many congregations the liturgy is helter-skelter. There is no rational sequence to it. It's just an assemblage of items, arranged for psychological effect, or perhaps strung out with no rationale at all. Another issue is that far too seldom do people understand the nature of the liturgical act that they are performing. Its structure and meaning and function are obscured from them.

(Wolterstorff 1992:298)

\section{DIE GESONGE EN GESPROKE WOORD VAN GOD}

In die Ou-Testamentiese tyd, waar liedere in die tempeldiens deur tempelsangers namens die volk gesing is, het dit aan beide die verkondigings- en responskant van die liturgiese gebeure gefunksioneer. Uit die Nuwe Testament blyk ook dat die lied van die Christelike gemeente 'n dubbele gerigtheid het: vertikaal en 
horisontaal. Dit is uitdrukking van lof, danksegging en dus respons - maar dit is óók verkondiging. Dit is aanbidding, maar dien óók tot wedersydse geloofsopbou (1 Kor 14:12; 15-17; 26), horisontale geloofsgesprek (Ef 5:19), lering (didaskalia) en vermaning (Kol 3:16). Die Reformatore, Luther en Calvyn, het sterk by hierdie Bybelse uitgangspunte aangesluit en het die noue verhouding tussen woord en musiek as 'n kenmerk van die erediens beklemtoon. In die reformatoriese tradisie is egter so sterk klem gelê op die Woord dat 'n eensydige beklemtoning van "woord as medium", dus die gesproke woord, ook daarmee gepaard gegaan het.

Die argument dat die lied "nie verkondiging of getuienis is nie, maar antwoord op God se woord" en dat "slegs die prediking God se woord kan verkondig", is en word nog dikwels in reformatoriese kringe aangevoer ( $\mathrm{vgl}$ Kloppers 1999:297). Voorstanders van dié argumente beroep hul meestal verkeerdelik op Luther en Calvyn (Smelik 1995:33). Die rigiede uitgangspunte wat veral in die Gereformeerde Ortodoksie gevolg word, is eerder 'n oorbeklemtoning van Zwingli se standpunte (vgl Jenny 1983 vir 'n uitgebreide bespreking van die drie Reformatore se uitgangspunte).

Volgens Luther is musiek 'n wesenlike deel van menswees - 'n skeppingsgawe van God, en daarom ook 'n wesenskenmerk van die kerk. Volgens hom is musiek die beste middel om geloof te verklank. Deur musiek kan die gemeente ook verkondigend betrokke wees. Daarvoor is alle musiek in beginsel geskik. Musiek het volgens Luther dus twee funksies: om die woord te verkondig én om te dien as uitdrukking van geloof. Soos die preek, is musiek die viva vox evangelii - die lewende stem van die evangelie (Luther WA 1983: Tischreden 2545b). Dit moet die teks klank, dit is lewe gee. In aansluiting by Luther, en deur te wys op die menslike element in die prediking, toon Blankenburg (1979:298; 301) dat sang inderdaad verkondiging kan wees. Hy beklemtoon dat die prediking nie oor die goddelike openbaring beskik nie, maar dat selfs die getuienisse in die Skrif menslike media is.

Verkondiging geskied deur 'n verskeidenheid media, soos die gesproke én gesonge woord. Sing en sê is nie teenoorstaandes nie, maar slegs twee 
verskillende wyses waarop taal klank kry - die onderskeid is nie 'n wesenlike onderskeid nie, maar ' $n$ modale onderskeid. Die gesproke Woord is dus nie méér God se woord as die gesonge woord nie. Die mens "verneem" ook nie slegs deur die gesproke woord nie, maar ook deur die gesonge woord. Blankenburg waarsku teen 'n verabsolutering en sakralisering van die prediking wat gebeur wanneer verkondiging uitsluitlik met die "kanselrede" gelykgestel word: "Können wir uns die Verkündigung der 'großen Taten Gottes' im Ernst nur gesprochen vorstellen?... Kann der Glaube nicht auch gerade dadurch erweckt werden, daß 'die großen Taten Gottes' gepriesen werden und Christus in aller Freudigkeit vor der Welt bekannt wird?" (Blankenburg 1979:303-307).

Sang in die erediens funksioneer dus nie net as belydenis nie - nie net as antwoord op God se woord nie, maar ook as verkondiging (vgl Kloppers \& Dreyer 1994:583-609). Woord en antwoord, verkondiging en lofprysing is deur die hele erediens onskeibaar met mekaar verweef. Van Wyk (2001:890) sluit nog sterk by die woord-antwoord skema aan en sê met verwysing na Van Uchelen (1983/1971): "Gelowiges se antwoord lê 'n verklaring af van hulle geloof, doen verslag van God se goeie dade aan hulle." Die vraag is of gelowiges aan God self verslag doen van Sy goeie dade aan hulle (deur Hom te antwoord) en of gelowiges nie juis teenoor mekaar getuig van God se goeie dade, en sodoende ook verkondig nie?

Van Wyk verwys na my standpunte ten opsigte van dié saak (Kloppers 1999:297) en sê dit "beteken dat die kerklied nou nie meer net draer van die gemeente se antwoord op die woord is nie, maar dat dit self ook verkondiging word. ... Dié verskuiwing is nie noodwendig verkeerd nie, maar behoort baie dieper beredeneer te word" (Van Wyk 2001:893). Dit kom voor asof daar by hom dus wel 'n bepaalde openheid vir die saak bestaan, onder voorwaarde dat dit dieper beredeneer moet word. Ek het die saak inderdaad reeds diepgaande en meer omvangryk beredeneer (Kloppers 1992; 1994; Kloppers E C 1997) ten einde juis teologies aan te toon hoe omvattend die moontlikhede van die kerklied én musiek in die erediens is, en om te poog om teologiese en himnologiese eensydighede in die lig van nuwere teologiese en antropologiese uitgangspunte te oorkom. 
Daar kan nooit 'n totale skeiding of onderskeiding gemaak word tussen wat God se woord en die mens se antwoord in die erediens sou wees nie, omdat God se woord vervat is in menslike getuienis aangaande die ontmoeting met die lewende God. Hierdie getuienis geskied ook deur 'n verskeidenheid simboliese handelinge in die erediens en deur die erediens as simboliese handeling. Ons sing in die erediens omdat ons God ontmoet het, Hom gehoor het, in ons ganse wese aangespreek is, en om uitdrukking te gee aan hierdie geloofservaring. Die lied as simbolies-kommunikatiewe handeling vervul 'n wesenlike funksie in die totale geloofservaring wat deur die erediens te weeg gebring word.

In laude confitentis est praedicatio - Augustinus

\section{TAAL ÓF MUSIEK - 'N ONHOUDBARE TEENSTELLING}

Naas eensydige beklemtonings ten opsigte van die woord-antwoord skema, is ook al ongeldige onderskeide tussen taal en musiek gemaak wat die saak nie ten goede kom nie. In 'n resensie van die werk van Pass (1989) lewer Van Wyk (1991) kritiek op Pass se poging tot die daarstel van 'n teologie van die kerkmusiek. Van Wyk verwys na Karl Barth se "bekende uitspraak dat die openbaring van God alleen in die woord vervat is". Hy sluit aan by De Bruijn (1982) se kritiek op Söhngen (1967) se poging tot 'n "teologie van musiek" en waarvolgens De Bruijn sê dat taal wel 'n boodskap het, maar musiek nie.

Musiek het wel invloed, positief of negatief, maar kan musiek so 'n uniforme inwerking hê dat vir alle gelowiges daarmee dieselfde boodskap duidelik word? Kan musiek byvoorbeeld die vergewing van sonde vertolk? Taal is op die verstand gerig en daarom baie meer eenduidig as musiek, wat op die gevoel gerig is. ... Algemeengeldende uitsprake kan nie deur musiek gemaak word nie. Musiek het nie op alle gelowiges dieselfde uitwerking nie.

(Van Wyk 1991:883)

Hierdie afspeel van taal teenoor musiek, is 'n ongeldige onderskeid. Taal werk net soos musiek deur middel van assosiasie, selfs al kan taal feitelik meer 
konkreet be-teken vanweë die semantiese verwysingsmoontlikhede waarop reeds ooreengekom is. Die meerdimensionaliteit, "multiple meaning" (vgl Ricoeur 1974:63) van taal word egter deur bogenoemde stellings misken. Die vrae kan omgekeer word: Het taal so 'n uniforme werking dat vir alle gelowiges daarmee dieselfde boodskap duidelik word? Volgens die resepsieteorieë van Jauß en Iser (vgl Wegenast 1991:40) kan verskillende lesers dieselfde teks verskillend of selfs teenstrydig verstaan.

As die werking van taal so uniform en seker is, waarom word daar so dikwels oor teologiese en geloofsuitsprake verskil? Alhoewel taal inderdaad meer op die rasionele of kognitiewe vlak kan kommunikeer, gaan dit in die oordrag en aanvaarding van geloof nie om die rasionele instemming met feitelike waarhede nie. Die vraag is ook of taal wel die vergewing van sonde kan vertolk? Die vergewing van sonde gaan nog altyd ons logika, ons verstand en spreke te bowe. Die analoë of metaforiese kommunikasiewyse van taal en geloofstaal, word in dié argument dus misken.

Is taal ook sonder meer op die verstand en musiek slegs op gevoel gerig? Sekere uitsprake deur middel van taal wek immers baie emosie op. Taal het dus ook nie op alle gelowiges dieselfde (emosionele) uitwerking nie. "Algemeengeldende uitsprake kan nie deur musiek gemaak word nie" (vgl Van Wyk hierbo). Is uitsprake in taal egter so algemeen-geldend? Verskeie hedendaagse studies rakende taal, die werking daarvan en betekenisgewing daardeur, toon die teenoorgestelde aan (vgl onder meer Zilleßen 1991:70-71; Grözinger 1991:4557). Het musiek nie dalk 'n groter universele werking as taal nie en ontmoet kulture mekaar nie dikwels veel meer oor grense heen deur middel van musiek nie?

Storr (1992) verwys na Mendelssohn wat sê dat 'n woord nie dieselfde vir een persoon as vir ' $n$ ander beteken nie, maar dat "only the tune says the same thing, awakens the same feeling, in both" (Storr 1992:70). Storr bewys die saak dan verder met behulp van empiriese navorsingsresultate. Vanselfsprekend geld dié bewyse ook nie absoluut nie, maar dit toon die teenkant van die argument rakende die eksaktheid van taal. 'n Oortuigende bewys dat musiek 'n invloed op 
die werking van die brein het en dus ook op die kognitiewe vlak funksioneer, blyk uit resente studies wat veral ten opsigte van die musiek van Mozart gedoen is daar word selfs gepraat van die Mozart-effek (vgl Campbell 1997). 'n Aantal studies het getoon dat veral Mozart se musiek die vermoë om drie-dimensioneel te dink verbeter. Met behulp van rekenaars is vasgestel dat Mozart se musiek gekenmerk word deur langtermyn siklusse wat waarskynlik bepaalde invloede op sekere funksies van die brein het. Mense het sekere take vinniger aangeleer wanneer Mozart se musiek tydens die leerproses gespeel is. Hierdie studies toon dat musiek ook 'n invloed op die verstand het en kan meewerk om 'n mens iets te laat aanleer of iets te laat verstaan.

Indien geredeneer word dat dit nie moontlik is om musiek ook op verstandsvlak te waardeer nie, kom ook die algemeen-gangbare siening en verdediging van "gepaste" liturgiese musiek wat tot dusver binne die Reformatoriese tradisie in Suid-Afrika gehandhaaf word, in 'n ernstige dilemma, omdat daar ook aanspraak gemaak word op die kwessie van verstaan van die "goeie" musiek en met rasionele (verstandmatige) argumente aangetoon word watter kriteria vir kerkmusiek behoort te geld. Wanneer woord en musiek, soos dikwels ook woord en beeld, as konkurrente gestel word (vgl Heimbrock 1993:70; Kloppers W C 1997:23-45; 114-130) dui dit op 'n verabsolutering van die gesproke taal of redevoering as sou dié woord Woord van God self wees. Dit bring ook 'n ernstige verskraling van musiek se verbeeldingsmoontlikhede en die assosiatiewe moontlikhede op geloofsvlak te weeg, wat selfs die teenwoordigheid daarvan in die erediens kan skaad.

\section{VERKONDIGING DEUR MUSIEK: DIE ROL VAN ASSOSIASIE}

Die assosiasie wat deur musiek geskep word het dikwels 'n sterk verkondigingsfunksie. Op 'n sterfbed waar byvoorbeeld die woorde van 'n lied nie meer logies bedink kan word nie, kan die musiek vir 'n lied nog deur middel van assosiasie 'n vertroostende en geloofsversterkende funksie hê - vgl Kloppers (2000) ten opsigte van die pastorale en helende funksie van musiek; Heimbrock (1993:71) 
en Otto (1988:332) ten opsigte van musiek in grenssituasies; en Marti (1994:267) wat juis vanuit hierdie situasies ook die ruimte maak vir musiek sonder teks. Met die hoor van 'n koraalverwerking of -voorspel van 'n bekende psalm of gesang, word assosiasie met die woorde gewek. So verkondig musiek ook deur middel van assosiasie. J S Bach het in sy kantates meesterlik van assosiasie gebruik gemaak deur byvoorbeeld saam met die stemparty(e) wat 'n aria, koraal of resitatief sing, die melodie van 'n bekende gesang in die instrumentale begeleiding aan te haal. Dit is dus nie net die eksplisiete woorde van die aria of resitatief wat verkondig nie, maar ook die implisiete woorde van die gesang wat deur assosiasie aangehaal word. Die assosiasie met die implisiete woorde kan so ook die betekenis en belewenis van die eksplisiete woorde versterk. Musiek as vorm van simboolkommunikasie het dus veral deur assosiasie verreikende moontlikhede.

Deur die assosiasie wat musiek by die hoorder kan oproep, kan die hoorder die teenwoordigheid van God beleef en die "Woord van God" hoor (vgl Knellwolf 1989:49-55; Kloppers 1997:159-216). Dit gaan hier nie om die een óf die ander nie (vgl Luther se siening van die beelde - Luther WA 37:63, Grözinger 1991:51), maar om beide in 'n Gesamtverständnis. lemand wat nog nooit die verbale boodskap van God en sy verlossingsdade in en deur Jesus Christus gehoor het nie (hetsy deur die prediking, hetsy deur die liedere), gaan waarskynlik nie deur die blote hoor van musiek tot geloof gebring word nie. 'n Persoon wat egter reeds die evangelie van Jesus Christus gehoor het, maar vir 'n geruime tyd miskien nie meer in die erediens kom nie, kan deur die onverwagse hoor van sekere musiek wat hy/sy met die erediens én dus met die evangelie assosieer, opnuut God se Woord hoor - deur God aangespreek word in die herinnering wat deur die musiek na vore gebring word.

'n Persoon wat in verre lande reis, verstaan miskien nie die vreemde taal waarin gesing of gepreek word nie, maar hoor dikwels in die melodie die bekende boodskap. Sou die geproke woord, die redevoering of preek, in al hierdie gevalle 'n beter vorm, of die enigste vorm van verkondiging kan wees? Die assosiasie wat in musiek geleë is, kan dus net soveel, en soms selfs meer, 'n 
medium van verkondiging wees as die assosiasie wat in woorde geleë is. Blankenburg (1979) kom weer ter sprake: Kan ons ons die verkondiging van die groot dade van God werklik net gesproke voorstel?

\section{LITURGIESE EENSYDIGHEDE}

It is not difficult to predict what will happen when proclamation, centered in the sermon, becomes the overwhelmingly dominant action of the liturgy : all that might distract our attention will be stripped away, up to the point where the congregation sits in silence, lined up in rows in a well-lit white box, listening. ... By contrast, where proclamation is not allowed to overwhelm the liturgy, where the dimension of worship is given its rightful place, there the richness of life will put in its appearance. There color and gesture and movement and peace and sound wil enter as vehicles of praise and gratitude.

Wolterstorff (1986:159)

Wolterstorff (1992:273) verwys na die "genius of the Reformed liturgy", maar toon dat dit dikwels niks méér as "the issuing of marching orders" is nie. Hy wys daarop dat die "worship" dimensie, die dimensie van aktiewe en vreugdevolle deelname aan die erediens en die lofprysende reaksie op God se handeling onderdruk word ten gunste van die preek (hortatory address) en die na binnegekeerdheid in die erediens. "Liturgy is divine and human interaction" (Wolterstorff 1992:297-299).

Ek is daarvan oortuig dat dit juis die vroeëre oorreaksie téén musiek en ander vorme van verkondiging is wat sekere teenreaksies en negatiewe praktyke tot gevolg gehad het. Ek het reeds gewys op die vreemde onderskeid ten opsigte van liturgiese ordes vir "gewone eredienste" en liturgiese ordes vir "Woord- en Lieddienste" in die Diensboek (1997) wat soos volg lui: "Enige een van die Liturgiese ordes ... word gebruik, waarby die Woord- en liedgedeelte as aanloop voor die votum of as afloop na die seën gebruik word" (Diensboek 1997:50 - my kursivering). Ek het gevra na die teologiese motivering vir so 'n siening en of die vooraf-gegewe liturgiese ordes gekanoniseer is téénoor "Woord- en lied"? Wat is "Woord- en lied" binne so 'n verdeling? Tog skriflesing 
en sang - maar skriflesing en sang wat buite die liturgiese orde moet funksioneer? (Kloppers 1999:294).

Hierdie onderskeid spruit vanuit die onhoudbare teenoorstelling van woord en sang, van Singen und Sagen. In alle eredienste behoort woord en sang immers onlosmaaklik met mekaar verweef te wees. Dikwels hoor 'n mens ook predikante sê dat hulle 'n "liturgiese diens" hou, bedoelende 'n erediens met meer sang. Beteken dit dat eredienste waar minder gesing word nié liturgies is nie? Wolterstorff stel dit duidelik: "The Reformed liturgy is the Reformed service" (Wolterstorff 1993:277).

Die Diensboek vertoon bykans geen trekke van die liturgiese vernuwing wat die afgelope eeu in reformatoriese en ander kerke oor die hele wêreld plaasgevind het nie - en soos onder meer ryklik geïllustreer in die Dienstboek een proeve (1998) van die Nederlandse Samen op Weg Kerke. Soveel van die ordes in die huidige Diensboek van die Nederduitsch Hervormde Kerk is in wese dieselfde en laat min ruimte vir meer aktiewe deelname en die rol wat sang ten opsigte van die verkondiging en al die liturgiese handelinge kan vervul (Kloppers E C 1997:335-337; 1999:294-295).

Eensydige klemtone het die sang reeds in baie opsigte negatief beïnvloed en het baie bygeda tot die strak, formalistiese en ongeïnspireerde sangpraktyke wat in baie gemeentes heers. 'n Mens hoor selfs orreliste dikwels sê dat as die prediking net weer "regkom", die eredienste as geheel weer sal "regkom". Daaruit blyk by orreliste 'n skreiende gebrek aan 'n breër liturgiese bewussyn. So word die wesenlike rol wat sang en orreliste/musiekleiers self, as mede-liturge, moet speel, genegeer. So 'n standpunt van orreliste dien dikwels ook as verskoning vir 'n gebrek aan 'n geïnspireerde (en inspirerende) rol in die erediens. Die preek of gesproke woord word as geïnspireerd, as "goddelike spreke" beskou, en die sang as menslike handeling - dit wat gevolglik ook na willekeur verander kan word om die menslike smaak te pas. In die Diensboek (1997:4-5) word die sang as antwoord beklemtoon: die verkondigingsaspek word sydelings genoem, maar daar word slegs op die antwoord-aspek uitgebrei. Dit beklemtoon 'n siening van sang as blote menslike handeling. 
Verskraling en afskaling van enige aspekte van sang en spreke lei onvermydelik tot 'n ernstige verskraling van sang en verkondiging in die breë, van die liturgiese gebeure as sodanig, en uiteindelik van die gemeentelike lewe as geheel. ' $n$ Teologie wat die innerlike samehang met musiek verloor het, is volgens Luther sinloos, omdat dit nie meer die geheimenisvolle samehang van sing en sê, sang en spreke, erken nie (vgl Möller 1995:11).

... what also results from the suppression of the worship dimension of liturgy is the seriousness, the sobriety, the absence of joy so characteristic of the traditional Reformed liturgy and so contrary to the spirit of the divine rest and people's liberation that we are intended to mirror. ... unless the worship dimension receives due emphasis throughout the liturgy, proclamation will be received with a form of ethical seriousness that excludes joy.

Wolterstorff (1983:159-160)

\section{MUSIEKBEDIENING?}

Die evangelie word inderdaad deur 'n groot verskeidenheid media gekommunikeer (verkondig) en ervaar - ook deur musiek. Verskillende kerke se inslag en spiritualiteit verskil egter sodanig, dat daar groot onderlinge verskil ten opsigte van die aard van die verkondiging en ervaring deur musiek kan wees. Wanneer die saak "musiekbediening" ter sprake kom, sal daar vanselfsprekend ook groot onderlinge verskil wees. 'n Kerk kan egter nie die saak afwys, omdat dit deur ander kerke en denominasies op 'n wyse gedoen word wat vir 'n bepaalde kerk onaanvaarbaar sou wees - omdat dit nie binne die aard van daardie kerk se teologie, spiritualiteit en kommunikasievorme inpas nie. Musiekbediening as 'n ander term vir musiekverkondiging of verkondiging deur musiek, is 'n saak wat ook binne die aard en teologie van die Nerderduitsch Hervormde Kerk 'n wesenlike plek behoort te hê.

Pass (1989) sê dat die betekenis van musiek "in ons kop is" en nie in die musiek nie, en dat alle musiekstyle daarom geskik sou wees om die evangelie te kommunikeer. Dat die betekenis van musiek "in ons kop" is, is waar, want deur assosiasie ken ons betekenis aan musiek toe (vgl Speelman 1995) soos ons ook 
deur middel van assosiasie met die tekens en simbole van taal betekenis aan taal toeken. Dat alle musiekstyle in beginsel geskik sou wees om die evangelie te verkondig, is inderdaad ook waar, omdat geen styl "gesanksioneer" is nie (vgl Luther hierbo). Die beginsel van assosiasie maak egter juis sommige style meer aanvaarbaar as ander en kan sekere style en idiome vanweë bepaalde assosiasievorming, ook minder aanvaarbaar maak (vgl Kloppers 1995:199-202). Musiek wat 'n sterk assosiasie met byvoorbeeld 'n danssaal of 'n disco te weeg bring, is tog minder geskik vir die erediens as musiek wat oor eeue met kerk en erediens geassosieer word, en wat juis vanweë die assosiatiewe krag 'n vorm van verkondiging moontlik maak. Waar musiekbediening net deur middel van pop- en rockmusiek geskied, blyk dit dikwels dat die ritmiese aspek en volume so oorheersend is, dat die talige teks verdring word, wat weer beteken dat die musiek 'n soort "alleenverkondiger" word - maar met musikale middele waarvan die assosiasie vreemd is aan die aard van die erediens. Die probleem ontstaan veral waar 'n erediens as geheel met pop- en rockmusiek ingerig word.

Daar behoort in eredienste voorsiening gemaak te word vir 'n verskeidenheid van style en vorme, sodat "ligter" musiek ook náás die meer tradisionele" kerkmusiek 'n plek kry, én andersom (vgl Strydom 1994:279-292). Daar mag nie eensydig besluit word dat sekere ouderdomsgroepe net deur pop-en rockmusiek aangespreek word en daarom net aan dié soort musiek blootgestel word nie. Alle ouderdomsgroepe en generasies moet aan verskeidenheid blootgestel word - dié verskeidenheid waardeur die verskillende geloofsnuanses (lof, aanbidding, belydenis, pyn, berou) juis gekommunikeer kan word. So kan die onderskeie (geloofs)verwagtings, behoeftes, en ouderdomsgroepe aangespreek word, en meerdere gawes geakkommodeer word. Op dié wyse kan die volle omvang van die evangelie inderdaad in ryker verskeidenheid verkondig word.

Die oorheersende rol wat die prediker in die eensydige "woorddiens" speel, word tans tereg bevraagteken, en "meerdere deelname" word bepleit. Dit is dikwels juis die voorstanders van "meerdere deelname" wat op voorsangers en begeleidingsgroepe aandring, om sodoende "meer gawes van lidmate" geleentheid te gee. Met dié beginsel is geen fout te vind nie. Maar waar voorsangers of dikwels selfs ' $n$ enkele sanger, 'n sanggroep of orkes egter in 'n bepaalde vorm 
van musiekbediening ook weer 'n oorheersende of eensydige rol begin speel, gebeur dit dikwels dat die gemeentesang gesmoor, en die aktiewe deelname deur die volle gemeente tot passiwiteit verval. Verkondiging deur musiek of musiekbediening wat eensydig gesien word as 'n soort popfees wat in één bepaalde styl, met behulp van die instrumente van 'n poporkes (en dikwels ook met Amerikaanse-Engelse tekste) plaasvind, is vreemd aan die uitgangspunte, teologie, aard en inslag van die Nederduitsch Hervormde Kerk. Dit is juis die saak van assosiasie, soos aangetoon, wat 'n mens dwing om sekere sake af te wys.

Hiermee is aangetoon dat sekere vorme van "musiekbediening" binne die "etos" of inslag van die Nederduitsch Hervormde Hervormde Kerk minder of nié aanvaarbaar sou wees nie. Die beginsel van "musiekbediening" behoort egter onderskryf en bevorder te word. Myns insiens is die term "musiekbediening" egter ' $n$ eensydige term wat ook reeds (soos aangetoon) met verkeerde konnotasies of assosiasies gelaai is, en daarom liefs nie gebruik behoort te word nie. 'n Term wat die omvattende saak van alle vorme van verkondiging insluit, behoort gebruik te word. Terme soos musiekverkondiging, kunsverkondiging, visuele- en estetiese verkondiging en kreatiewe geloofskommunikasie, kom ter sprake. Uiteindelik kan al die terme saamgevat word onder die breë term verkondiging of bediening - wat alle aspekte van verkondiging of bediening behoort te omvat. Die term "verkondiging" is egter tot dusver weer nié so omvattend beskou nie. In afgrensing dus ook van die eensydige gebruik van die woord verkondiging, lyk die breër term kreatiewe geloofskommunikasie veral geskik te wees.

\section{KREATIEWE GELOOFSKOMMUNIKASIE IN DIE EREDIENS}

Kreatiewe geloofskommunikasie as omvattende strategie kan eers ten volle ontplooi word as eensydighede binne die liturgie as geheel aangespreek word. Teenoor 'n eensydige teologiese siening waarvolgens die lidmaat na die erediens kom om met die Woord bedien te word (en meestal net deur die gesproke woord) word die gemeente as liggaam van Christus wat bepaalde gawes ontvang het om mee te dien, toenemend beklemtoon. Lidmate wil meer aktief by die erediens 
betrokke wees en wil op 'n kreatiewe wyse as volle deelnemers aan die kommunikatiewe (simboliese) handelinge in die erediens meedoen. Die aanbiddingsdimensie moet dus veel meer erken word (vgl Wolterstorff hierbo). Dit beteken ook dat die emotiewe, affektiewe, konatiewe en sosiale dimensies van die volle mens in berekening gebring moet word en nie slegs die kognitiewe of verstandelike aspek nie.

Ruimte moet dus geopen word vir die volle deelname van almal in verbeeldingryke eredienste waar musiek en ander vorme van verkondiging deur kuns, voorstellings, stilte en bepaalde handelinge, net so 'n groot rol speel as die gesproke woord om die Woord van God uit te dra. Luther se standpunt in sy voorwoord by die Gesangboek van 1524 wat sê dat alle kunste - in die besonder musiek - in diens van Hom wat alles geskep het moet staan, is nog net so geldig en behoort weer opnuut ontdek te word. Musiek en ander kunsvorme kan op verskeie wyses in diens staan van die evangelie, of die evangelie bedien.

Ten opsigte van die musiek beteken dit dat daar in die erediens sprake moet wees van liedere wat deelname bewerkstellig, wat uitnooi tot deelname, en liedere wat simboliese waarhede (geloofswaarhede) kan bemiddel - dus liedere met sterk kommunikatiewe waarde. Musiek en kuns kan die Woordverkondiging (kerugma), pastoraat, koinonia en marturia dien, en ook 'n integrale deel van alle aspekte van kreatiewe geloofskommunikasie vorm. Die breër onderbou van hierdie saak is reeds uitgebreid beredeneer op die terrein van die liturgie en die kerklied, sowel as op die visuele en breë estetiese vlak (Kloppers E C 1997; Kloppers W C 1997).

Die nuwe Liedboek van die Kerk (2001) bied ingrypende nuwe moontlikhede tot verantwoordelike vernuwing in aansluiting by die vernuwing wat reeds wêreldwyd plaasgevind het. Met die Liedboek is liturgiese vernuwing in die Afrikaanse Reformatoriese kerke vooruit geloop in dié sin dat moontlikhede vir meerdere deelname en betrokkenheid gebied word wat tot dusver onbekend in dié kerke was. Hierdie nuwe moontlikhede moet sinvol en verantwoordelik, en ook in lyn met die historiese en ekumeniese verband, gebruik word. Dit is nie sinvol om liedere en vorme in aansluiting by die liturgiese vernuwing in kerke met 'n soortgelyke "etos" of inslag as dié van die Nederduitsch Hervormde Kerk te 
ontsluit, wanneer dit volgens die voorbeeld van charismaties-geörienteerde kerke aangewend word - soos byvoorbeeld om response as "koortjies: (chorusses) te gebruik wat oor en oor herhaal word, óf om liedere sonder verband aaneen te ryg net om 'n bepaalde "gevoel" of "atmosfeer" te skep nie. Die ordes in die Diensboek kan ook nou met liedere en vorme uit die liedboek verryk word - veral sodat predikante en kerkrade wat streng aan dié vorme vashou en dit helaas nié as riglyne sien nie, geleentheid het tot 'n meer buigsame en kreatiewe inrigting van die liturgie.

Benewens nuwe vorme, soos response, waar die gemeente die geleentheid gebied word om kollektief te antwoord; die gebruik van ('n verskeidenheid) voorsangers in afwisseling met die gemeente; kanons (waar 'n gemeente meerstemmig kan sing), is daar ook liedere wat uitstekend as "prosessieliedere", as intog- of uittogliedere vir die kantory, kerkraad of kinders kan funksioneer (bv LvdK 160 en 317). Hierdeur word die geleentheid gebied dat lidmate ook op meerdere wyses kan deelneem. Die styl en aard van liedere verskil onderling ook veel meer as in vorige liedboeke. Hierdie pluraliteit voorsien in uiteenlopende behoeftes ten opsigte van die erediens, en die verskillende persoonlikhede en generasies in die erediens. Verder is die begeleidingsmoontlikhede in die begeleiersboek uitgebrei vir meerdere instrumente naas of saam met die orrel, waardeur die geleentheid geskep word om die verskeidenheid musikale gawes van lidmate te benut (vanselfsprekend is die moontlikhede nie beperk tot dit wat in die begeleiersboek aangedui word nie.) Die voorbeelde en praktiese benutting van liedere en verskillende vorme ten einde die lidmate ten volle te betrek en meerdere deelname te bewerkstellig, is legio en word nie hier omvattend bespreek nie. Die uitdaging vir liturge en musiekleiers is om binne die eie tradisie nuut en kreatief te dink. Die rol van die liturg-erediensleier-musiekleier en dié van musiekleier-orrelis-mede-liturg moet ook kreatief en nuut bedink word.

Kreatiewe geloofskommunikasie in die praktyk moet inderdaad noukeurig bedink en beoefen word. Die beplanning van die erediens en sinvolle inrigting van die liturgie kan slegs plaasvind vanuit grondige besinning en met al die elemente van spreke, musiek, stilte, beeld kuns, en dies meer, geïntegreer in 'n omvattende vorm van kreatiewe geloofskommunikasie. Onkundige en onverant- 
woorde optrede kan lei tot gebruike wat vreemd is aan die eie kerklike tradisie en wat, as dit eenmaal tot groei gekom het, weer moeilik uitgeroei kan word. Identiteitvorming geskied immers in die erediens en in die besonder deur al bogenoemde (kuns)vorme en handelings. Dit beteken egter ook dat die aard van die identiteit wat so gevorm word, met groot omsigtigheid hanteer moet word ( $\mathrm{vgl}$ Daiber 1992:17-18). Grondige opleiding is onontbeerlik.

\section{DIE OPLEIDING VAN LITURGE}

Seminaries in the Reformed tradition spend months and years teaching their students the theory and practice of preaching; they dispose of liturgy in a week or so. ... And those in the tradition who do become liturgical scholars must practice their scholarship on the side. The pattern is too pervasive to be accidental, especially in view of the fact that the Reformed tradition neglects neither the practice of liturgy nor the pursuit of learning. Though it values liturgy and learning, it places no value on liturgical learning.

$$
\text { Wolterstorff (1992:273-274 - my kursivering) }
$$

Die opleiding van liturge, veral met betrekking tot kerkmusiek, himnologie, kuns en die visuele was tot dusver baie gebrekkig en selfs afwesig - soos Wolterstorff ook duidelik aantoon. Mense sonder formele opleiding op die terrein doseer dikwels die vakgebied (of eerder, aspekte van die vakgebied). Die kerk beskik gevolglik oor liturge (musiekleiers inbegrepe) sonder voldoende liturgiesestetiese vorming. Daar is reeds vroeër gepleit vir die breë estetiese vorming van predikante en 'n omvattende kommunikasiestrategie vir die kerk (Kloppers W C 1997:196-231; 343-372). Dit kan egter nie bedink word terwyl die nodige opleiding ontbreek nie. Die deeglike opleiding van dosente, predikante, kerkmusici en alle ander betrokkenes - liturgies en himnologies, veral met die oog op die sinvolle en effektiewe gebruik van die nuwe liedboek, maar ook visueel en op 'n breë estetiese vlak, is onontbeerlik ten einde kreatiewe geloofskommunikasie as omvattende saak, met "verkondiging deur musiek" daarby inbegrepe, in die praktyk ten volle te laat realiseer. 
Above all, men and women charged with liturgy need to be artists, aware of their responsibility not just to intone certain words and move in certain ways, but to fashion through it all a vision of the universe where order is sufficiently compelling to banish all doubt.

(Hoffman 1988:148)

\section{Literatuurverwysings}

Blankenburg, W 1979. Kirche und Musik: Gesammelte Aufsätze zur Geschichte der gottesdienstlichen Musik. Göttingen: Vandenhoeck.

Campbell, D 1997. The Mozart effect: Tapping the power of music to heal the body, strengthen the mind and unlock the creative spirit. New York: Avon.

Commissie voor het Dienstboek van het Samenwerkingsorgaan voor de Eredienst. 1998. Dienstboek - een proeve. Schrift - Maaltijd - Gebed. Zoetermeer: Boekencentrum.

Daiber, K F 1992. Gottesdienst unter den Bedingungen der gegenwärtigen Gesellschaft. Für den Gottesdienst 39/40, 9-20.

Grözinger, 1991. Sprache und Bild: Auf dem Weg zu einer elementartheologischen Hermeneutik, in Zilleßen et al, 45-57.

Heimbrock, H 1993. Gottesdienst: Spielraum des Lebens. Weinheim: Deutscher Studien Verlag.

Hoffman, L A 1988. The art of public prayer: Not for clergy only. Washington: Pastoral Press.

Ingelse, C et al 1995. Nieuw handboek voor de kerkorganist. Zoetermeer: Boekencentrum.

Jenny, M 1983. Luther, Zwingli, Calvin in ihren Liedern. Zürich: TVZ.

Kloppers, E C \& Dreyer T F J 1994. Liturgiese koorsang as wyse van kerklike verkondiging: 'n Prinsipiële besinning vanuit hermeneuties-homiletiese perspektief. HTS 50(3), 583-609.

Kloppers, E C 1995. Liturgical music: Worship or war? Dialog 34, 199-206, herdruk in HTS 53 (3), 172-184.

Kloppers, E C 1997. Liturgiese musiek as kommunikatiewe handeling in 'n postmoderne era. DTh- proefskrif: Universiteit van Suid-Afrika. 
Kloppers, E C 1999. Kerkmusiek: 'n Beskeie bydrae?, in Van Wyk 1999:286299.

Kloppers, E C 2000. Ubi caritas et amor deus ibi est: Die Pastorale funksie van die kerklied. Praktiese Teologie in Suid-Afrika 15(2), 99-111.

Kloppers, W C 1997. Die kommunikatiewe vermoë van die parateks van kerkpublikasies. DTh-proefskrif, Universiteit van Suid-Afrika.

Knellwolf, U 1989. Die Musik im reformierten Gemeindegottesdienst, in Musik in der evangelisch-reformierten Kirche: Eine Standortbestimmung, 45-86. Zürich: Institut für Kirchenmusik der Evangelisch-Reformierten Landeskirche des Kantons Zürich.

Liedboek van die Kerk 2001. Kaapstad: NG Kerk-Uitgewers.

Luther, M 1883. Werke. Kritische Gesamtausgabe. Weimar (WA)/ Weimarer Ausgabe Tischreden.

Marti, A 1994. Verordnet aus dem Volk? Kirchengesang zwischen Herrschaftsinstrument und Mittel der Emanzipation. MuG 1, 6-16.

McKim, D K (ed) 1992. Major themes in the Reformed tradition. Grand Rapids: Eerdmans.

Möller, C 1995. "Ein neues Lied wir heben an". Der Beginn des reformatorischen Singens im 16. Jh. und die Einführung eines Evangelischen Gesangbuches am Ende des 20. Jh. Referat beim zweiten ökumenischen und interdisziplinären Seminar zum Kirchenlied, Kloster Kirchberg.

Nederduitsch Hervormde Kerk van Afrika 1997. Diensboek. Pretoria: Kital.

Nederduitsch Hervormde Kerk van Afrika 2001. Agenda. 66ste Algemene Kerkvergadering.

Nederduitsch Hervormde Kerk van Afrika 2001. Besluitebundel. 66ste Algemene Kerkvergadering.

Otto, G 1988. Handlungsfelder der Praktischen Theologie. Praktische Theologie Band 2. München: Kaiser.

Pass, D B 1989. Music and the church: A theology of church music. Nashville: Broadman.

Ricoeur, P 1974. The conflict of interpretations. Evanston: Northwestern University Press. 
Rößler, D 1996. Lob - Lehre - Labsal: Theologie im Spiegel von Musik, Kirchenlied und Gesangbuch. IAH-Bulletin 24, 57-76.

Smelik, J 1995. Opvattingen over muziek in de kerkgeschiedenis, in Ingelse, C et al 1995:25-41.

Söhngen, O 1967. Theologie der Musik. Kassel: Stauda.

Speelman, W M 1995. The generation of meaning in liturgical songs: A semiotic analysis of five liturgical songs as syncretic discourses. Kampen: Kok.

Storr, A 1992. Music and the mind. New York: Free Press.

Strydom, W M L 1994. "Sing nuwe sange, nuutgebore": Liturgie en lied. Bloemfontein: UOVS.

Van Wyk, D J C 1991. Resensie: Pass, D B 1989, Music and the church: A theology of music. HTS 47(3), 882-884.

Van Wyk, D J C 1999. 20ste eeu Hervormde Teologie. Pretoria: Sentik.

Van Wyk, D J C 2001. Ons kerklied: Prinsipiële en praktiese oorwegings. HTS $57(3 \& 4), 882-907$

Wegenast, K 1991. Hermeneutik und Didaktik, in Zilleßen et al 1991:23-43.

Wolterstorff, N 1983. Until justice and peace embrace. Grand Rapids: Eerdmans. Wolterstorff, N 1992. The Reformed liturgy, in Mc Kim, D K (ed), Major themes in the Reformed tradition, 273-304. Grand Rapids: Eerdmans.

Zilleßen, D (Hrsg) 1991. Praktisch-theologische Hermeneutik, Ansätze - Anregungen - Aufgaben. Rheinbach-Merzbach: CMZ Verlag.

Zilleßen, D 1991. Religionspädagogische Lernwege der Wahrnehmung, in Zilleßen et al 1991:59-85. 